\title{
Physiological Quality of Cowpea Seeds Produced in Southwestern Nigeria
}

\section{Olasoji J.O. ${ }^{1 *}$, Olosunde A.A. ${ }^{2}$ and Okoh J.O. ${ }^{3}$}

\author{
${ }^{1}$ Institute of Agricultural Research and Training, Obafemi Awolowo University, Moor Plantation \\ Ibadan, Nigeria. \\ ${ }^{2}$ National Centre for Genetic Resources and Biotechnology, Moor Plantation, Ibadan. \\ ${ }^{3}$ University of Agriculture, PMB 2373, Markurdi.
}

\section{ARTICLE INFO}

Article No.: 10031279

DOI: 10.15580/GJAS.2013.6.10031279

Submitted: 10/03/2013

Accepted: 22/06/2013

Published: 29/06/2013

*Corresponding Author

Olasoji J.O.

E-mail: juliusolasoji@yahoo.com

\section{Keywords:}

Cowpea, locations, electrolyte, leakage, seedling length
The experiment was conducted at the Institute of Agricultural Research and Training, Obafemi Awolowo University, Moor Plantation, Ibadan to determine the physiological qualities of cowpea seeds produced in rain forest environment. Six varieties of cowpea produced in two different locations were collected from the Legume Improvement Programme of the Institute. There were two experiments for this study. Electrolyte leakage was determined using 3 replicates of 50 pre weighed seeds with JENWAY 4510 digital electrical conductivity meter, while sterilized river bed sand was used for standard germination. All laboratory tests were conducted using the complete randomized design (CRD).

The results showed that variety and location had significant $(p<0.05-0.001)$ effects on germination percent (GCPT), germination rate index (GRI) and seedling length. Interaction between variety and location also had significant $(p<0.01)$ effects on GCPT, GRI and seedling length. There were significant differences $(p<0.05)$ among the varieties with respect to the germination percent. GCPT ranged from $66.67 \%$ in IT90k-227-2 to $92.67 \%$ in Ife BPC with overall means of 78.33. GCPT was higher in cowpea seeds produced in Ibadan than that produced in lle-lfe. Number of abnormal seedlings was not statistically different from one another. Overall germination percent of the cowpea produced in Ibadan was $88.44 \%$ and the percentage was lower in Ile-lfe. Results also revealed that conductivity value was low in seed produced in Ibadan which is an indication of high quality seed over those produced in Ile-Ife. From the results of this experiment it can be deduced, that high quality seeds of cowpea can be produced in Ibadan and some other parts of the State that fall under transition environment. 


\section{INTRODUCTION}

Quality seeds of improved varieties are the key to agricultural progress. The production potential and other desirable characteristics of seeds set the limits on production. Other inputs such as fertilizers, pesticides, herbicides and overall crop management also help to realize the production potential of seeds. Today, cowpeas are grown worldwide with Africa producing the largest share. Langyintuo et al., (2003) estimated that 3.7 million $\mathrm{mt}$ of cowpeas were annually produced on about 9.7 million hectares during the 1990s in Africa, the Americas, Europe and Asia, of which west and Central Africa accounted for 2.6 million $\mathrm{mt}(69 \%$ of the world's production) on 7.8 million hectares $(80 \%$ of the world harvested area). As individual countries imply, Nigeria the largest cowpea grower in the world, accounted for $45 \%$ of the world production, followed by Brazil (17\%), and Niger (10\%) during the same period. Although "cowpea is a warm-season crop well adapted to many areas of the humid tropics and temperate zones" the drier areas in West Africa have a comparative advantage in producing legumes, compared to humid areas, because pests and disease make production in the humid areas more difficult (Langyintuo et al., 2003). The primary cowpea production zone in West and Central Africa lies between the 300 and $1,000 \mathrm{~mm}$ annual rainfall (Langyintuo et al., 2003). Cowpea is mainly produced in the Northern and Upper West Regions (Nimoh, 2004).

Environmental conditions acting on the mother plant, influence seed performance during germination (Wulf 1995; Hilhorst and Toorop, 1997; Salisbury and Ross, 1992). However, it is not clearly understood how the effects of

the environment during plant growth affects seed quality. Therefore the experiment was carried out to determine the effects of the environment on cowpea seeds in produced in two different agro-ecologies respectively.

\section{MATERIALS AND METHODS}

The experiment was carried out in the Seed Testing Laboratory of the Institute of Agricultural Research and Training (I.A.R\&T), Obafemi Awolowo University, Moor Plantation, Ibadan, Oyo State. Seeds of six (6) varieties of cowpea produced in two different stations (Ibadan and Ile-Ife) were collected from the Grain Legume Improvement Programme of the Institute. Ibadan and lle-Ife represent 2 different agro-ecological zones in the southwestern part of Nigeria namely; transition and rainforest ecologies, respectively.

\section{Laboratory experiments}

All laboratory experiments were carried out using Complete Randomized Design (CRD) replicated 3 times with 50 seeds per replication for each experiment

\section{Conductivity test}

Electrolyte leakage was measured from 50 clean and intact seeds per replicate incubated for 24 hours in $250 \mathrm{ml}$ flasks containing $100 \mathrm{ml}$ of sterile distilled water at about $25^{\circ} \mathrm{C}$ using JENWAY 4510 conductivity meter. The flasks were covered with aluminum foil to prevent contamination and were gently shaken at 5 hours interval. Electrical conductivity was measured in 3 replicates with the electrical conductivity of seed leachates measured using an electrical conductivity meter according to Seed Vigor Testing Handbook (AOSA, 1983) and reported as $\mu \mathrm{S} / \mathrm{cm} / \mathrm{g}$.

\section{Standard germination}

Sterilized river bed sand was used for standard germination. The sand was sieved with $2 \mathrm{Mm}$ sieve to ensure uniform particle size. Seed germination was measured by placing 50 seeds per replication in sand inside a plastic bucket and covered with moist sand up to about $2 \mathrm{~cm}$ level. The buckets were kept at warm temperature of about $25^{\circ} \mathrm{C}$ for 7 days after which the germination percentage was determine according to the Association of Official Seeds Analyst (AOSA) guidelines (AOSA, 1983). All the data collected from the seed quality tests were subjected to analyses of variance (ANOVA). Using general linear model and significant means, they were separated using least significant difference (LSD)

\section{RESULTS AND DISCUSSION}

Combined analysis of variance for germination test traits and seedling length was presented in table 1 . The result showed that variety and location had significant $(p<0.05$ 0.001) effects on germination percent (GCPT), germination rate index (GRI) and seedling length. Interaction between variety and location also had significant $(p<0.01)$ effects on GCPT, GRI and seedling length. 
Table 1: Analysis of variance table showing Means Square values of germination traits and seedling length

\begin{tabular}{lcccccc}
\hline Sources of Variance & DF & ABN & GCPT (\%) & GI & GRI & SDL \\
Replicate & 2 & 4.33 & 61.44 & 0.001 & 0.47 & 8.00 \\
\hline Variety & 5 & 28.20 & $519.84^{\star * *}$ & 0.002 & $4.23^{*}$ & $19.28^{*}$ \\
Location & 1 & 2.78 & $3173.44^{\star * *}$ & 0.003 & $23.55^{\star * *}$ & $27.09^{\star}$ \\
Variety x location & 5 & 7.04 & $463.31^{\star *}$ & 0.001 & $4.95^{\star *}$ & $23.85^{\star *}$ \\
Error & 22 & 13.78 & 56.72 & 0.00 & 0.06 & 5.11 \\
Total & $\mathbf{3 5}$ & & & & & \\
\hline
\end{tabular}

${ }^{*},{ }^{* *},{ }^{* * *}$, significant at $0.05,0.01$ and 0.001 level of probability

ABN: Abnormal seedling, GCPT: Germination percentage, GI (DAS): germination index, GRI (DAS):

Germination rate index, SDL: seedling length in centimeter, DAS: days after sowing

Influence of variety on germination traits was presented in table 2. There were significant differences $(p<0.05)$ among the varieties with respect to germination percent. GCPT ranged from $66.67 \%$ in IT90k-227-2 to $92.67 \%$ in Ife BPC with overall means of 78.33 . With respect to germination index, there were no significant differences among the varieties. This implies that the speeds of germination in all the varieties are similar. Germination rate index varied. Highest GRI was recorded by Ife-98-12 followed by IT90k-227. Germination rate index indicates the number of days that will take a seed lot to have $100 \%$ germination. From the results, it will take both Ife-98-12 and IT90k-227-2 6.43 and 5.69 days to attained $100 \%$ germination

Table 2: Mean values of germination trait and seedling length of six cowpea varieties

\begin{tabular}{lccccc}
\hline \multicolumn{1}{c}{ VARIETIES } & ABN (\%) & GCPT (\%) & GI(DAS) & GRI(DAS) & SDL(cm) \\
\hline Erusu & $5.67 \mathrm{ab}$ & $82.33 \mathrm{~b}$ & $4.02 \mathrm{ab}$ & $4.60 \mathrm{bc}$ & $29.28 \mathrm{~b}$ \\
IFE Brown & $1.67 \mathrm{~b}$ & $78.33 \mathrm{bc}$ & $4.01 \mathrm{ab}$ & $5.35 \mathrm{ab}$ & $33.17 \mathrm{a}$ \\
IFE BPC & $1.67 \mathrm{~b}$ & $92.67 \mathrm{a}$ & $4.00 \mathrm{~b}$ & $4.265 \mathrm{c}$ & $31.48 \mathrm{ab}$ \\
IFE-98-12 & $3.67 \mathrm{ab}$ & $71.00 \mathrm{~cd}$ & $4.05 \mathrm{a}$ & $6.43 \mathrm{a}$ & $32.27 \mathrm{a}$ \\
IT 90k-227 & $6.67 \mathrm{a}$ & $66.67 \mathrm{~d}$ & $4.00 \mathrm{~b}$ & $5.69 \mathrm{ab}$ & $33.25 \mathrm{a}$ \\
MODUPE & $5.67 \mathrm{ab}$ & $83.33 \mathrm{~b}$ & $4.00 \mathrm{~b}$ & $4.47 \mathrm{bc}$ & $34.45 \mathrm{a}$
\end{tabular}

Means with same letter are not significantly different at $5 \%$ level of probability.

ABN: Abnormal seedling, GCPT: Germination percentage, Gl: Germination Index, GRI: Germination Rate Index, SDL: Seedling length.

Table 3 showed that GCPT was higher in cowpea seeds produced in Ibadan and lower in that of lle-lfe. The production environment was in favour of seeds produced in Ibadan and is in line with the work of Holhost and
Toorop, (1997), which states that interaction between environments modify the ultra structure of developing seed and untimely seed quality.

Table 3: Mean values of germination traits and seedling length across location

\begin{tabular}{cccccc}
\hline LOCATION & ABN(\%) & GCPT (\%) & GI (DAS) & GRI (DAS) & SDL(cm) \\
\hline IBADAN & $4.44 \mathrm{a}$ & $88.44 \mathrm{a}$ & $4.00 \mathrm{a}$ & $4.33 \mathrm{~b}$ & $33.19 \mathrm{a}$ \\
IFE & $3.89 \mathrm{a}$ & $69.67 \mathrm{~b}$ & $4.02 \mathrm{a}$ & $5.94 \mathrm{a}$ & $31.45 \mathrm{~b}$ \\
\hline
\end{tabular}

Means with the same letter(s) along the same columns are not significantly different $(P<0.05)$

Number of abnormal seedling was not statistically different from one another. Overall germination percent of the cowpea produced in Ibadan was $88.44 \%$ and the percentage was lower in lle-Ife. For $100 \%$ germination, it will take seeds produced in Ibadan 4 days and 6 days for those produced in Ile-Ife. Seedling length was higher in cowpea seeds produced in Ibadan due to early and uniform germination. The main factors (variety and location) had significant effect $(p<0.01-0.001)$ on the concentration of the leachate as measured by the bulk conductivity (Table 4). 
Table 4: Mean square values of conductivity test traits of 6 cowpea varieties

\begin{tabular}{|c|c|c|c|c|c|}
\hline Sources of Variance & DF & IW(g) & $F W(g)$ & $\mathrm{WI}(\mathrm{g})$ & $\operatorname{Cond}(\mu \mathrm{S} / \mathrm{cm} / \mathrm{g})$ \\
\hline Replicate & 2 & 0.28 & $1.03^{*}$ & 1.79 & 96.9755 \\
\hline Variety & 5 & $3.27^{* \star *}$ & $22.29^{\star \star \star}$ & $9.50^{* * *}$ & $1431.91^{* * *}$ \\
\hline Location & 1 & $8.41^{* * *}$ & $75.69^{* * *}$ & $33.64^{\star * *}$ & $597.31^{\star *}$ \\
\hline Variety $x$ location & 5 & $2.06^{\star *}$ & $2.06^{\star *}$ & 12.62 & 39.68 \\
\hline Error & 22 & 0.35 & 0.35 & 0.90 & 70.77 \\
\hline
\end{tabular}

Interaction effect of variety $x$ location was only significant $(p<0.01)$ on initial weight (IW) and final weight $(F W)$. Effect of variety average over location on bulk conductivity was presented in table 5 . Conductivity reading ranged from $48.48 \mu \mathrm{S} / \mathrm{cm} / \mathrm{g}$ in Modupe to 88.93 in IT90k-227-2. Conductivity which is a measured ${ }^{* *}$ of the membrane integrity showed that in all the varieties across the 2 locations, IT90k-227-2 had the highest value which is an indication of low seed quality.

Table 5: Mean values of Conductivity test traits of cowpea cultivars

\begin{tabular}{lcccc}
\hline Varieties & IW(g) & FW(g) & WI(g) & Cond $(\mu \mathbf{S} / \mathbf{c m} / \mathbf{g})$ \\
\hline ERUSU & $6.76 \mathrm{~b}$ & $14.23 \mathrm{~d}$ & $7.46 \mathrm{c}$ & $49.57 \mathrm{c}$ \\
IFE Brown & $6.87 \mathrm{~b}$ & $15.90 \mathrm{c}$ & $9.02 \mathrm{~b}$ & $60.84 \mathrm{~b}$ \\
IFE BPC & $7.06 \mathrm{~b}$ & $16.96 \mathrm{~b}$ & $9.90 \mathrm{~b}$ & $49.46 \mathrm{c}$ \\
IFE-98-12 & $8.76 \mathrm{a}$ & $20.00 \mathrm{a}$ & $11.27 \mathrm{a}$ & $57.18 \mathrm{bc}$ \\
IT90-K & $7.03 \mathrm{~b}$ & $15.96 \mathrm{c}$ & $8.93 \mathrm{~b}$ & $88.93 \mathrm{a}$ \\
MODUPE & $7.42 \mathrm{~b}$ & $17.06 \mathrm{~b}$ & $9.64 \mathrm{~b}$ & $48.48 \mathrm{c}$ \\
\hline
\end{tabular}

Mean with same letters(s) along the same column are not significantly different $(P<0.05)$

IW:- Initial weight, FW:- Final weight, WI:- Water Imbibe, Cond.: Bulk conductivity

Table 6 showed the conductivity test traits values for the 2 locations. Average initial weight of all the varieties combined was higher in the seeds produced in Ibadan and lower in Ile-Ife. Similar trend was followed by both final weight and water imbibed after soaking for $24 \mathrm{~h}$. The conductivity reading was low in seeds produced in
Ibadan which is an indication of high quality seed over those produced in lle-Ife. The results of the laboratory seed quality

tests revealed that cowpea seeds produced in Ibadan had the highest overall germination percentage. Seeds produced in Ibadan also had the lowest conductivity 
reading which is an indication of high quality seed over those

produced

in

Ile-Ife.

Table 6: Mean value of conductivity test traits across locations

\begin{tabular}{llccc}
\hline LOCATION & IW(g) & FW(g) & WI $(\mathbf{g})$ & Cond $(\boldsymbol{\mu S} / \mathbf{c m} / \mathbf{g})$ \\
\hline IBADAN & $7.81 \mathrm{a}$ & $18.14 \mathrm{a}$ & $10.34 \mathrm{a}$ & $55.01 \mathrm{~b}$ \\
IFE & $6.84 \mathrm{~b}$ & $15.24 \mathrm{~b}$ & $8.41 \mathrm{~b}$ & $63.15 \mathrm{a}$ \\
\hline
\end{tabular}

Mean with same letter are not significantly different at $5 \%$ level of probability.

IW: Initial weight, FW: Final weight, WI: Water Imbibe, Cond. : Bulk conductivity

\section{REFERENCES}

AOSA (1993): Seed Vigor testing handbook, contribution No.32 to the Handbook of Seed Testing Association of Official Seed Analyst.

Hilhorst, H. W. N and Toorop, P. E. (1997): Review on dormancy germinability and germination in crop and weed seeds. Advances in Agronomy 61, 113-165.

Langyintuo, A.S., Lowenberg-Deboer J., Faye $M$, Lambert G., Ibro G., Moussa B., Kergna A.,Kushwaha S., Musa S., and Ntoukam G. (2003) : Cowpea supply and demand in west and central Africa. Field Crops Res. 82 (2), p. 215-231.
Nimoh, F. (2004). Consumer preference and market opportunities for processed cowpeabased products in the coastal regions of Ghana. M.Phil. Thesis, Department of Agricultural Economics and Agribusiness, University of Ghana-Legon..

Salisbury, F.B \& Ross, C.W. (1992): Plant physiology, $4^{\text {th }}$ Ed. Wadworth Belmont, California, U. S. A

Wulf, R. D. (1995): Environmental material effects on seed quality and germination In: Seed Development and Germination. Kigel, J and Galili, G. (eds) mercel Dekker Inc. NewYork U. S. A. 